\title{
Colombia, conflict and the rule of law
}

\author{
by Anna Doyle
}

Dr Judith Maldonado Mojica, director of Carlos Perez Lawyers Collective (CCALCP), a Colombian association dedicated to defending human rights in the region of Norte de Santander, spoke at the IALS on November 29, 2010. The following article provides an insight into the context of practising human rights law in Colombia based on the experience of the Colombian Caravana UK Lawyers Group, who travelled to Colombia in August 2010 as part of an international delegation seeking to provide a link between Colombian human rights lawyers and the legal community worldwide.

\section{INTRODUCTION}

The phrase "without lawyers there is no justice" is particularly resonant for human rights lawyers in Colombia. It is a country where threats and violence are routinely made against defenders of human rights, intended to deter them from carrying out their work. It goes without saying that human rights law in Colombia is heavily bound up with the ongoing 40-year internal armed conflict. This is true to such a degree, however, that human rights defenders in Colombia struggle to prove the legitimacy of the work they do and to establish the rule of law as the governing principle of human rights practice. High-profile politicians, including former president Álvaro Uribe, have repeatedly linked human rights defenders to insurgency and terrorism. This has added to a climate in which targeted violence towards human rights defenders can occur with impunity, further diminishing confidence in the rule of law. Yet Colombian human rights lawyers are continuing their work in spite of the many difficulties they face, in order to ensure that the rule of law is upheld even in situations directly arising from the armed conflict.

With this in mind, participants in the second International Delegation of Lawyers (known as the Caravana) travelled to Colombia on the invitation of ACADEUM, an umbrella organisation of human rights lawyers in Colombia. On the UK side, the delegation was co-ordinated as part of the ongoing work of the Colombian Caravana UK Lawyers group (Caravana UK). Driving this initiative is the need for lawyers internationally to lend support to their Colombian counterparts. Human rights lawyers in Colombia are campaigning for the simple right to exercise their profession freely, in the interests of ensuring help pursue this aim across Colombia, the delegation was split into several sub-groups each visiting a different part of the country for three days. In making the trip to Colombia, the 56 members of the Caravana had a dual aim: firstly, to provide a visible symbol of support for the human rights cause in Colombia, and secondly, to obtain the information needed to continue their advocacy on behalf of Colombian human rights lawyers after returning home.

\section{ARMED CONFLICT AND THE RULE OF LAW}

The obvious question for participants in the delegation was what progress had been made towards improving the situation of human rights lawyers since the previous delegation in 2008. Yet as long as the conflict continues to simmer just below the surface of everyday life in Colombia, the context in which its human rights lawyers are obliged to practise will remain highly unstable. Recent guerrilla attacks and military retaliations demonstrate that the armed conflict in Colombia operates outside the rule of ordinary civil and criminal law. The first few weeks of new president Juan Manuel Santos's incumbency, beginning on August 7 this year, saw an increase in violence across the country. Attacks attributed to FARC were launched in Bogotá, Pasto, Caqueta and Putumayo, killing over 50 police, members of the armed forces and guerrillas. The Colombian government responded in two separate attacks on FARC encampments between September 19 and 23, killing over 40 members of FARC including three of its leaders, most notably its second in command Jorge Briceño Suárez (better known as Mono Jojoy).

Amongst the challenges faced by human rights lawyers in Colombia is achieving the transposition of such events into an appropriate legal framework so that their clients' cases 
can be heard. This has historically been subject to official obstruction: in particular, through the allocation of all cases involving members of the security forces to the jurisdiction of the military courts. The unacceptability of this approach is illustrated by the infamous cases of "falsos positivos", in which the Colombian military carried out extrajudicial executions and framed the victims as guerrilla fighters, in order to appear to be winning the fight against insurgency. Allowing such cases to be heard in the military courts fostered impunity and opacity as attempts were made to cover up the full extent of the crimes. The Caravana was encouraged to learn that this issue has begun to be resolved, through the handover of a significant number of cases involving human rights issues from the military to the ordinary justice system. The challenge now is to resolve the large number of outstanding disputes as to which jurisdiction should apply. The uneasy co-existence arising in certain locations, where civilian justice institutions are located within military premises, also needs urgently to be addressed.

Restricting the scope and influence of military justice emerged as a clear priority of the victims of human rights abuses interviewed by members of the Caravana. The story of Pedro Paz Guerrero, a former policeman who met with members of the Caravana in the south-western city of Pasto, illustrates both the tragic confusions created by the conflict, and the difficulty of obtaining justice where cases fall under military jurisdiction. In 2004, Señor Paz
Guerrero's son, Mario Paz, also a policeman, was gunned down by members of the Colombian army along with six other members of his patrol, which was engaged in a hostage recovery operation. Six years on, and following the outcome of an initial military trial and subsequent retrial in the civil courts, Señor Paz Guerrero is still seeking justice for his son. Disillusioned with the Colombian justice system, he is now taking recourse to international law in order to resolve the unanswered questions surrounding his son's death.

Colombia does in fact have, at least on paper, a highly developed legal system, including an extensive framework of human rights legislation. A notable exception to the sophistication of human rights legislation in Colombia is law 975 of 2005, misleadingly known as the Justice and Peace law. Enacted as part of a transitional justice programme to encourage the demobilisation of paramilitaries, and the product of difficult negotiations with paramilitaries, the law is clearly deficient both in its content and its implementation. The maximum penalty available under the Justice and Peace law is eight years' imprisonment, for a crime that under the ordinary penal code could attract a 60-year sentence, raising questions about the extent to which it could ever achieve justice. This however has yet to be tested even five years after its implementation - to date, only two sentences have been handed down under the Justice and Peace process, despite the thousands of confessions made. In May 2008, the law

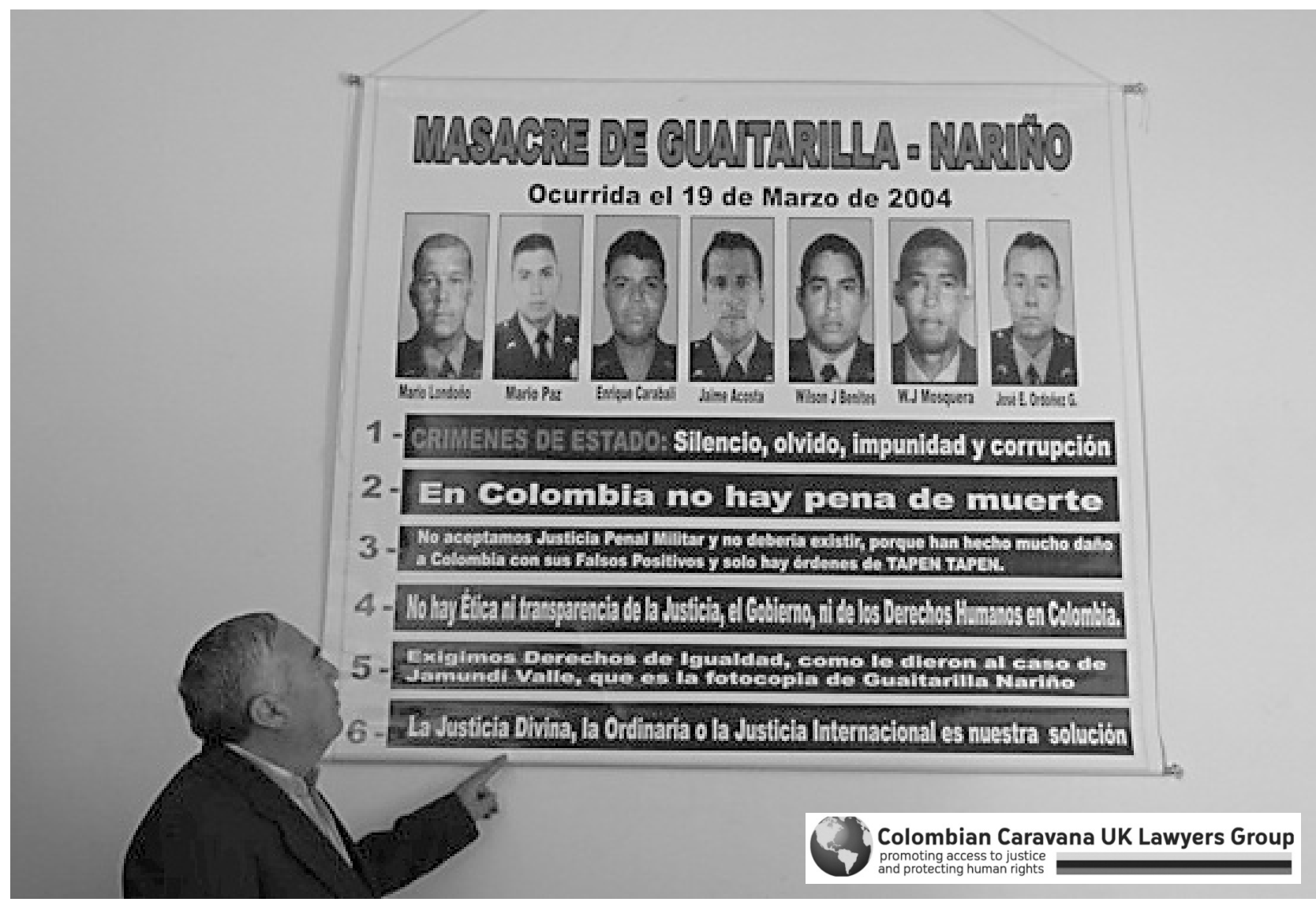

Pedro Paz Guerrero 
was further undermined by the extradition of 14 principal leaders of the AUC paramilitary group to the United States. Most of the 14 have by now dropped out of the justice and peace process and outside the scope of Colombian legal jurisdiction altogether.

\section{HUMAN RIGHTS DEFENDERS CAUGHT UP IN CONFLICT}

The volatility of the issues surrounding the conflict also means that those affected - on all sides - often seek to influence the outcome of cases from outside the boundaries of the legal framework. The result is that lawyers are effectively brought into the conflict, whether by remarks identifying them with the alleged actions and beliefs of their clients or by means of menaces from the groups whose interests are threatened by their work. Members of the Caravana travelling to Cúcuta (Norte de Santander) were hosted by the Luis Carlos Perez Lawyers' Collective (CCALCP), a group of women lawyers directed by Judith Maldonado, which provides legal assistance, education and accompaniment to farmers, displaced populations, indigenous people and trade unionists. Just two weeks before the group's arrival, Judith Maldonado had been the victim of a physical and verbal assault, in which death threats were made, on the steps of CCALCP's offices. She was assaulted by two armed men who had appeared at the scene on a motorbike. The attackers also stole documents and communication devices belonging to CCALCP

This was not the first time that Dr Maldonado has been targeted as a result of her work: in March 2010, a voicemail left on her mobile phone threatened a bomb attack in response to CCALCP's advocacy on behalf of the indigenous community of Motilón Bari. The Colectivo has been subject to persecution ever since it came into existence eight years ago. Email threats, accusations of involvement with terrorist organisations and wiretapping of lawyers by DAS, the Colombian state security department, are just a few examples. Members of the Caravana were told by CCALCP that the pressure resulting from such incidents has significantly increased since 2009, with the attacks becoming alarmingly systematic. Dr Maldonado has filed seven complaints in relation to direct attacks against her but none has been investigated, leading to complete impunity for the perpetrators. The work of CCALCP continues undeterred but protection for its members is urgently needed.

\section{LOOKING TO THE FUTURE}

Coming face to face with these issues during the two Colombian delegations has left a lasting imprint on international participants. The hope now is that an equally significant positive impact can be made to the lives of human rights lawyers, their clients and Colombians as a whole. From what began as a week-long delegation coordinated by the Law Society of England and Wales in 2008, the Caravana has developed into an independent, year-round project, with the UK group's applications for charitable status and funding currently underway. The initiative is still at an early stage and faces significant challenges. Resources, both human and financial, are thinly spread: Caravana UK, like ACADEUM, is run almost entirely by volunteers. Its aims are ambitious, however: the goal is to create a global network of lawyers to support, publicise and facilitate the work of Colombian human rights lawyers. Drawing the world's attention to the difficulties faced by human rights lawyers in Colombia is the initial priority, in order to mobilise further support and apply pressure on the Colombian government to address the situation.

The international launch of the Caravana's report on the 2010 delegation is planned to take place in January 2011, and will be followed by a lobbying programme to gain support from legal, political and diplomatic institutions world-wide, as well as securing the collaboration of the charitable and not-for-profit sector. The November 29 event will form part of a series of speaker events at which Colombian human rights lawyers will share their experiences with the international legal community. The backing of fellow legal professionals across the word is a powerful force, which will significantly increase the Caravana's potential to make an impact.

The work of the Caravana is focused on achieving a better future for Colombian human rights lawyers, as well as improving the current situation. There is some cause for optimism that the change in government may mean a change in the state's attitude towards human rights defenders. Developments since the delegation's return, however, make it clear that the armed conflict, which has such a significant impact on the practice of human rights law in Colombia, is far from resolved. And while the new president's unenviable task of achieving such a solution is incomplete, human rights lawyers in Colombia will need the support of their colleagues across the world to promote their cause and raise their profile, both within Colombia and internationally. In line with the group's founding principle that "without lawyers there is no justice", all members of the legal community have a part to play in upholding the rule of law through safeguarding the freedom to practise law, and promoting universal access to justice.

\section{Anna Doyle}

The author is a solicitor with DLA Piper UK LLP who travelled to Colombia in August 2010 as part of the Second International Delegation of Lawyers. 